\section{Fin gjennomgang og bevisstgjøring om akutt abdomen}

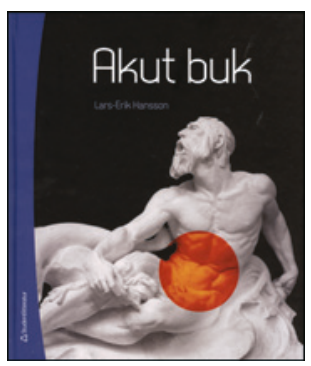

Lars-Erik Hansson

\section{Akut buk}

Diagnostik och behandling av akut buksmärta. 2. utg. 323 s, tab, ill. Lund: Studentlitteratur, 2013. Pris SEK 414 ISBN 978-91-44-05144-4

Lars-Erik Hansson er dosent og overlege i kirurgi ved Sahlgrenska universitetssjukhuset i Göteborg. For ti år siden ga han for første gang ut Akut buk, med ønsket om å forene oppsamlet og oppdatert forskning med omfattende klinisk erfaring om emnet. Nå har boken kommet ut i ny og oppdatert utgave. Han ønsker å gjøre det enklere for leseren å stille riktig diagnose ved akutt abdomen, og han henvender seg til både studenter, allmennleger og kirurger. Han favner bredt da han mener at buksmerter bør vurderes ut fra et større perspektiv enn kun fra spesialistens eller subspesialistens, da årsakene kan være såpass mangfoldige. I boken veileder han leseren gjennom velkjente diagnoser innen gastrokirurgi, men benytter også de første kapitlene til å greie ut om den diagnostiske og kliniske prosessen generelt, om buksmertens anatomi og fysiologi, om teknikker ved undersøkelse av pasienter og om differensialdiagnostikk.

Særlig interessante er kapitlene som omhandler ekstraabdominale årsaker til akutt buk, akutte og kroniske bukveggsmerter og kroniske buksmerter av psykogen og funksjonell opprinnelse. Disse delene er nye i denne andre utgaven, og de vil sannsynligvis kunne være til stor nytte for mange. I tillegg kommer de uspesifikke buksmertene som varierer i forekomst mellom $25 \%$ og nesten $40 \%$, ifølge tallmateriale som presenteres i teksten. Forfatteren redegjør også for hva han mener er god klinisk praksis og om forskjellene mellom mindre og mer erfarne klinikere i den diagnostiske prosessen.

Boken kan beskrives som en generell lærebok, men også som en helhetlig og relativt kortfattet innføring i måten å tenke på som diagnostiserende lege ved både akutte og kroniske magesmerter. Leseren blir guidet gjennom stoffet på en omtenksom og nesten faderlig måte, som i hvert fall tiltaler undertegnede som fortsatt er en forholdsvis ung og relativt uerfaren lege i spesialisering innen generell kirurgi. Det kan likevel tenkes at boken er vel grunnleggende for mer erfarne og drevne kolleger, og noen vil nok oppfatte den mer som et supplement til annen og mer velkjent litteratur innen generell kirurgi enn som et referanseverk. For undertegnede ble det en fin gjennomgang og viktig bevisstgjøring av en del som var velkjent fra før, men også mye som var nytt.

Med forbehold om at man har et avslappet forhold til å lese på svensk, er boken velskrevet og lettlest. Enkelte temaer er kanskje noe overfladisk dekket, men det gjøres klart fra forfatteren at han ikke vil gi en komplett innføring i alle detaljer. Snarere er hans poeng at ettersom våre kollektive kunnskaper som yrkesgruppe bare øker og $ø$ ker, blir det paradoksalt nok vanskeligere for det yrkesutøvende individet å bli trygg på det basale. Verdien er stor i å holde kompliserte temaer enkle, og viktigheten av å få en oversikt og å lære seg mentale verktøy for å komme i mål diagnostisk understrekes.

Jeg synes forfatteren lykkes meget godt. Dette er en bok jeg vil ha nytte av i lang tid fremover. Jeg anbefaler den særlig til medisinstudenter og mindre erfarne leger i spesialisering, men jeg tror også at mer erfarne kolleger vil ha nytte og glede av å lese den.

\section{Hvordan bli kvitt plunder og heft}

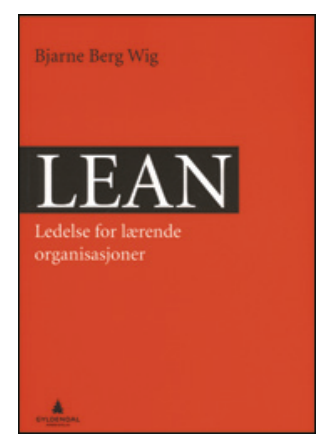

\author{
Bjarne Berg Wig \\ Lean \\ Ledelse for lærende organisasjoner. 216 s, \\ tab, ill. Oslo: Gyldendal Akademisk, 2013 \\ Pris NOK 369 \\ ISBN 978-82-05-42445-6
}

Forfatteren gir en innføring i bruk av kvalitetsforbedringsmåten Lean som endringsverktøy, og målgruppen er primært ledere i kommuner og bedrifter. Boken er i tre deler, hvorav første del er en introduksjon og bakgrunn for Lean som endringsverktøy i organisasjoner. Del to er en redegjørelse for verktøyene og praktisk bruk av disse. I del tre beskriver forfatteren hvordan organisasjoner kan bli lærende organisasjoner.

Grunnprinsippene er forbausende lik prinsippene som alltid har gjeldt i helsevesenet: Det skal være orden, gode prosedyrer og forutsigbarhet enten det er på operasjonsstuen, i skyllerommet eller i medisinrommet. Plunder og heft kalles det på sykehus om ting ikke er der de skal være, eller om man må bruke unødvendig lang tid på å vente på røntgensvar eller starte opp PCen.

Et viktig poeng i denne teksten er at organisasjoner lenge har vært preget av industriell tenkning, og at sykehusene er intet unntak. Selv om Lean kommer fra bilindustrien, representerer den et skifte vekk fra tradisjonell spesialisttenkning og styringsbyråkrati som tidligere preget samlebåndsindustrien, og som preger sykehus i dag. Sykehusenes spesialisering og søkelys på enkeltoppgaver og effektivitet har vært inspirert av Taylor og Ford siden tidlig på 1900 -tallet. Når bilindustrien nå tar lærdom av sin utvikling for å bli mer kundeorientert og læringsorientert, er det forventet at sykehusene følger etter.

Boken er imidlertid ikke tilpasset helsevesenet, og man omtaler begreper som er uvante. Det største ankepunktet er den lemfeldige presentasjonen av begreper som typisk preger «management»-litteraturen. Begreper og japanske ord blir brukt for å gi en illusjon av dybde, som slagord eller for å pirre nysgjerrigheten mer enn for å gi innsikt. Hva mener egentlig forfatteren med utrykk som «gemba, sensei», «turmatiserte mål» og «fra arbeid som effektivitet til arbeid som læring»? Slike uttrykk gir ikke presise beskrivelser av eller økt innsikt i feltet.

Teksten inneholder likevel interessante refleksjoner, og spesielt diskusjonen om hvorfor ulike organisasjonsløsninger går av moten, og det at kritikken mot ulike organisasjonsløsninger ofte er unyansert, er gode poenger som gjerne kunne vært mer utdypet. Boken er underholdende og går inn i sjangeren av preskriptiv «management»-litteratur som i liten grad forklarer hvorfor. Jeg anbefaler den for de som vil ha inspirasjon i forbedringsarbeidet, og som ønsker en rask oversikt over Lean-konseptene.

\section{Lars Erik Kjekshus}

Oslo universitetssykehus 